\title{
Spatial distribution of salinity, mud thickness and slope along mangrove ecosystem of the coast of Kupang District, East Nusa Tenggara, Indonesia
}

\author{
JERIELS MATATULA ${ }^{1,2, v}$, ERNY POEDJIRAHAJOE ${ }^{3, v \vee}$, SATYAWAN PUDYATMOKO ${ }^{3, v \vee v, ~}$ \\ RONGGO SADONO ${ }^{4, v w v}$ \\ ${ }^{1}$ Forestry Study Program, Master's Degree School, Universitas Gadjah Mada. Jl. Agro No. 1 Bulaksumur, Sleman 55281, Yogyakarta, Indonesia \\ ${ }^{2}$ Forestry Field Program, Politeknik Pertanian Negeri Kupang. Jl. Prof. Herman Johanes, Lasiana, Kupang 85011, East Nusa Tenggara, Indonesia. \\ Tel.: +62-380-881600, 881601, Fax.: +62-380-881601, ^email: jerielsforestry@ gmail.com \\ ${ }^{3}$ Department of Forest Resources Conservation, Forestry Faculty, Universitas Gadjah Mada. J1. Agro No. 1 Bulaksumur, Sleman 55281, Yogyakarta, \\ Indonesia. Tel.: +62-274-512102,6491420, Fax; +62-274-55541, vemail: er_pjr@yahoo.com, vw»email: spudyatmoko@ugm.ac.id) \\ ${ }^{4}$ Department of Forestry Management, Forestry Faculty, Universitas Gadjah Mada. Jl. Agro No. 1 Bulaksumur, Sleman 55281, Yogyakarta, Indonesia. \\ Tel.: +62-274-512102, 6491420, Fax; +62-274-55541, vw»email: rsadono@ugm.ac.id
}

Manuscript received: 11 February 2019. Revision accepted: 17 May 2019.

\begin{abstract}
Matatula J, Poedjirahajoe E, Pudyatmoko S, Sadono R. 2019. Spatial distribution of salinity, mud thickness and slope along mangrove ecosystem of the coast of Kupang District, East Nusa Tenggara, Indonesia. Biodiversitas 20: 1624-1632. Mangrove ecosystem is suffering from continuous damage in terms of quality as well as quantity. Rapid mangrove conversion triggered by the ever-growing human population and activities have affected them adversely and caused mangrove deterioration in the coastal areas of Kupang District, Indonesia. The decline of quality and quantity of mangrove environment has caused highly alarming effects, such as an increase in abrasion, decrease of marine products, and sea-water intrusion. Although various efforts have been deployed for the rehabilitation of mangrove forests, there are no significant results yet. One of the reasons is such efforts are not based on scientific data on suitability of the physicochemical conditions of the mangrove habitats. The objectives of this study were to analyze the physicochemical conditions, such as salinity, mud thickness and slope of five selected mangrove locations, namely Tarus, Mata Air, Tanah Merah, Oebelo and Merdeka in Kupang District by systematic sampling method and to prepare spatial distribution maps for each of these parameters. Salinity conditions showed a wide variation in the study locations, starting from $10 \mathrm{ppm}$ to $38.33 \mathrm{ppm}$. Mud thickness ranged from $20.11 \mathrm{~cm}$ to $84.77 \mathrm{~cm}$ in the entire study area. The highest mud thickness of $84.77 \mathrm{~cm}$ was found in Tanah Merah, followed by Oebelo with the maximum thickness of $74.66 \mathrm{~cm}$, Mata Air with $56.22 \mathrm{~cm}$, Merdeka with $53.66 \mathrm{~cm}$, and the lowest mud thickness was in Tarus with $53.55 \mathrm{~cm}$. Mangrove locations in Kupang District are dominated with 2-3\% slope. The study indicated that the habitat conditions in the coastal area of Kupang District are suitable for the growth of mangroves. This study will also provide the basis to plan future mangrove rehabilitation programs in the study area.
\end{abstract}

Keywords: Coastal area, coast inclination, mangrove growth, mud thickness, salinity level

\section{INTRODUCTION}

Mangroves perform many ecological functions, such as carbon absorption, pollutant remediation, abrasion prevention, intrusion prevention, besides acting as storm barriers. Mangroves are also the habitat for nurturing and breeding various aquatic species (Wiryanto et al. 2017). Mangroves hold the ability to increase marine production by $23 \%$ from the normal value (Anneboina and Kumar 2012). Mangroves even play important roles in preserving coastal areas from abrasion by providing stability in the sediments through its root system (Wiryanto et al. 2017). They also act as ocean pollutant filters to maintain the quality of marine water (Monsef and Smith 2018).

Mangrove ecosystems are inhabited by various animal species due to their ecological and physical features (Lapolo et al. 2018). Mangrove ecosystems also support various species of microorganisms which are highly tolerant to extreme conditions (Retnowati et al. 2017). Mangroves are important for preserving biodiversity, as well as for providing wood and non-wood products to local communities (Dharmawan et al. 2016). Mangrove ecology consists of various organisms, both living on land and in the water (Basyuni et al. 2018). Mangroves also protect small fishes and the larvae of fishes and clams, guarding them against predators (Lapolo et al. 2018). All these make mangroves very important elements in coastal ecosystems, in various aspects including ecological, social, and economical (Basyuni et al. 2018). Mangroves are globally limited by temperature. However, various factors, such as rainfall, tides, waves and river flow play very dominant roles in determining the distribution, width, as well as the biomass of mangroves in regional and local scales (Alongi 2008).

Globally, mangrove ecosystem gradually deteriorating both in quality and quantity due to human activities (Husodo et al. 2017). In return, condition of mangrove ecosystems also highly affect various human activities. Several factors such as land reclamation, construction works along the coastal line, as well as pollutions are the 
causes of mangrove ecosystem degradation (Husodo et al. 2017).

The core problem affecting mangrove forests in the coastal areas of Kupang District, Indonesia is the rapid land conversion triggered by an increase in population as well as human activities (Siubelan et al. 2015). This is threatening the very existence of mangroves (Matatula et al. 2018).

Various efforts have been implemented in the coastal areas of Kupang District to rehabilitate mangrove forests, but they have not shown significant results so far. The species used for rehabilitation activities were Rhizophora stylosa and Rhizophora apiculata. However, before deciding the species to be planted, no assessment of the physicochemical features of the mangrove habitats and their environment was conducted to find out whether these species are suitable. Actually, habitat features are important for deciding the species to be used in rehabilitation programs. Strategic planning on managing coastal area needs to be supported with studies about habitat characteristics in the mangrove areas, so that the mangrove rehabilitation efforts could yield better results. The objectives of this study are: (i) to understand the habitat conditions in terms of three selected physicochemical parameters, namely salinity, mud thickness and slope, of mangrove growing areas of the coastal region of Kupang District, East Nusa Tenggara, Indonesia, and (ii) to analyse the pattern of spatial distribution of these parameters and represent the same in the form of spatial maps.

\section{MATERIALS AND METHODS}

\section{Research areas}

This research was conducted in five mangrove locations of the coastal areas of Kupang District, East Nusa Tenggara, Indonesia, namely Tarus, Mata Air, Tanah Merah, Oebelo and Merdeka. Mangrove forests Tarus, Mata Air, Tanah Merah, Oebelo and Merdeka are located in the coastal area Kupang Bay that is the administrative area of Kupang district. The five location located in subdistricts namely Kupang Tengah and East Kupang. Kupang Bay is located at the position of $9.19^{\circ}-10.57^{\circ} \mathrm{S}$ and $121.30^{\circ}-124.11^{\circ} \mathrm{E}$. According to the government administration of Kupang Bay, it is included in 2 (two) regions, namely Kupang District and Kupang City, East Nusa Tenggara. Kupang Bay is one of the region irrigation conservation that has the complete ecosystem. One of the ecosystem potential that is mangrove ecosystem which extends to the coast of Kupang Bay. Map of the research locations is provided in Figure 1.

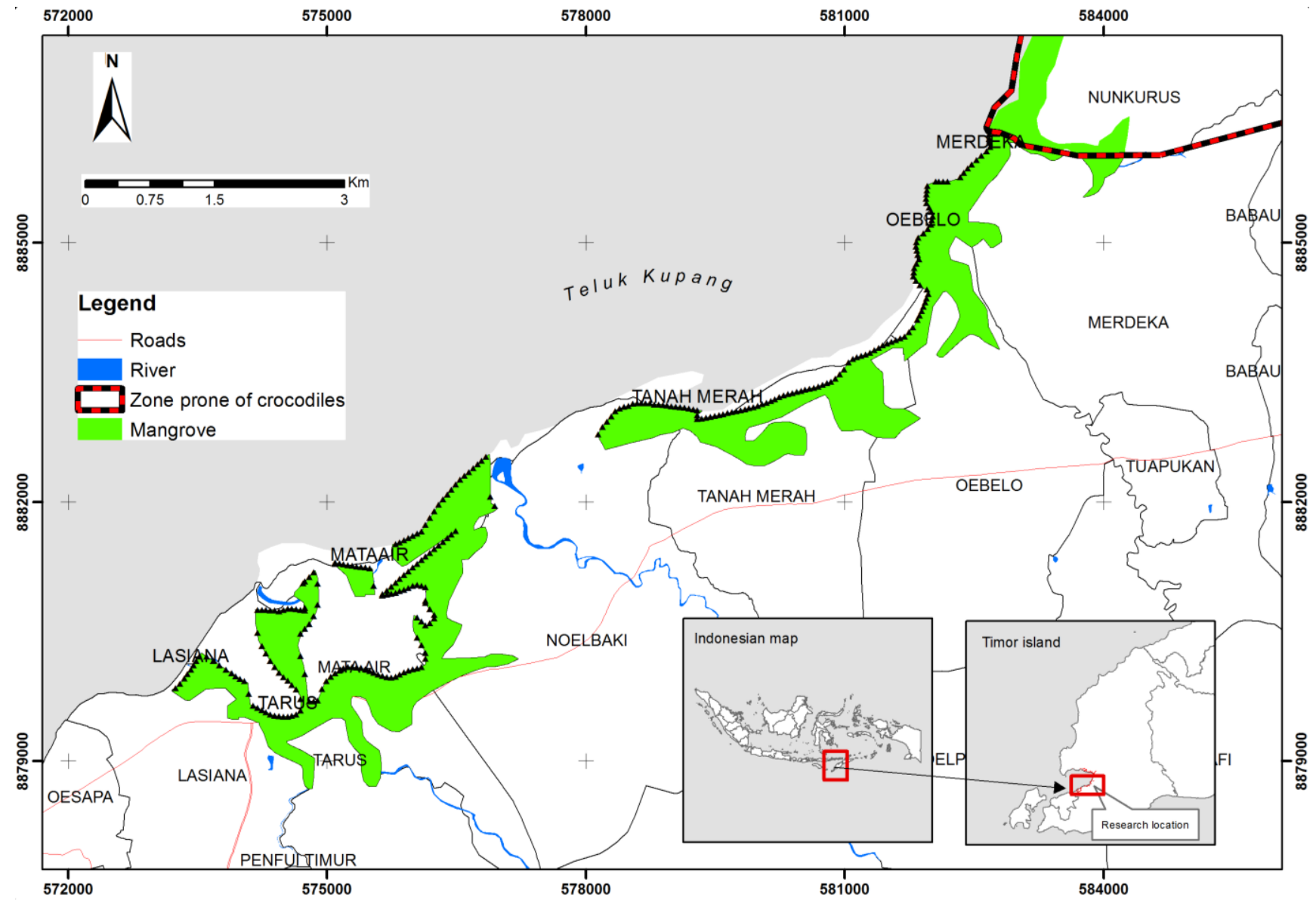

Figure 1. Map showing the mangrove research locations along the coastal area of Kupang District, East Nusa Tenggara, Indonesia 


\section{Physicochemical analysis}

Three parameters, namely salinity, mud thickness, and slope or coastal inclination were measured at different sampling points of each of the selected research sites, using proper sampling methods. Sampling and measurement were done in measuring grids which are placed perpendicular to the coastal line. On each research location, lines that were perpendicular to the coast-line which penetrate all the three zones of mangrove ecosystem (proximal, medial, and distal zones) were drawn. The distance between each line was 50 $\mathrm{m}$ horizontal to the beach. A total of 306 such lines were made in all the 5 research location, such as Tarus, Mata Air, Tanah Merah, Oebelo, and Merdeka. On each such line, three measuring areas or sampling plots (PU) of $10 \mathrm{~m}$ $\mathrm{x} 10 \mathrm{~m}$ were made, one in each mangrove zone.

Thus, a total of 918 (306 X 3) measuring areas were marked. Physicochemical parameters were analyzed in each of these 918 areas. All the measurements and samplings regarding salinity, thickness of mud and slope were taken only when the low tide starts. Salinity measurement of the mangrove areas was done using a refractometer. Salinity measurement was carried out by collecting water samples from each measuring area using spotting pipette, then the samples are dropped onto the detection sensor of the refractometer. The thickness of mud was measured using a scaled dip stick of $2 \mathrm{~m}$ length. The scaled stick was dipped into the mud until the tip touches the mud floor, then the mud thickness was read directly from the scaled stick. The tool used to measure the coastal slope was a clinometer.

The spatial mapping of the mangrove research locations for the distribution of studied parameters was done by grouping them into different classes, based on the values of each of the chosen parameters. For salinity, class G1included areas with low salinity of 10-20 ppm, G-2: areas with moderate salinity of 21-30 ppm and G-3: areas with high salinity of $>30 \mathrm{ppm}$. The mud thickness is also grouped into several depth classes: L-1: for mud thickness of 10-30 cm, L-2: for mud thickness of 31-40 cm, and L-3: for mud thickness of $>40 \mathrm{~cm}$. The grouping based on slope was S-1: for low slope (almost flat), the value is $\leq 1.5 \%$, S2: for moderate slope (flat to low), the value is $1.6-3.0 \%$ and S-3: For high slope flat to slope), the value is $\geq 3.0 \%$ (Poedjirahajoe 2006).

Cluster analysis was used to analyze the combined status of the mangrove habitat conditions. Cluster analysis will indicate the pattern of grouping of habitat conditions, the level of similarity or variations with regard to the studied physicochemical parameters between the different research locations located on the same stretch of beach. This analysis is based on calculating the mean Euclidean distance as proposed by Ludwing and Reynold (1988). The formula used was as follows:

$$
\operatorname{dij}=\sqrt{\frac{\sum_{k=1}^{m}(X i k-X j k)^{2}}{m}}
$$

Where:

Dij: Matrix data distance coefficient level i to level $\mathrm{j}$

$X$ ik: Parameters measured in level (experimental unit) $i$

$X \mathrm{jk}$ : Parameters measured in level (experimental unit) $\mathrm{j}$ $\mathrm{m}$ : Total parameters measured.

\section{RESULTS AND DISCUSSION}

\section{Physicochemical conditions of mangrove forest at Tarus}

Variations in salinity, mud thickness, and slope observed at different sampling points of mangrove location of Tarus is shown in Table 1. The salinity in this location ranged from $10 \mathrm{ppm}$ to $24 \mathrm{ppm}$. In Tarus, observation lines 1-18 showed salinity around $10 \mathrm{ppm}$ to $21 \mathrm{ppm}$, lines $19-35$ showed values ranging from $20.33 \mathrm{ppm}$ to $23 \mathrm{ppm}$, while lines 36-46 showed salinity value ranging from $18 \mathrm{ppm}$ to $19.33 \mathrm{ppm}$. On both ends of the observation stretch, lines showed low salinity levels as both of these locations are close to the estuary which contains mixture of fresh water and salt water. Salinity level in this location may be considered ideal for the growth of mangroves. This is because mangroves could thrive well in estuary with salinity level of $10 \mathrm{ppm}-30 \mathrm{ppm}$. Some mangrove species could even grow in places with high salinity level. For example, Avicennia marina can grow in high salinity water (Manurung et al. 2017). Salinity condition of Tarus mangrove location can be seen in Figure 2.

Mud thickness in Tarus was ranging from $20.11 \mathrm{~cm}$ to $53.55 \mathrm{~cm}$. Mud thickness becomes a determining factor for organisms such as Scylla serrata which is always active on mud while the tide is up (Widigdo 2017). Mud is the ideal growing place for mangrove vegetation. Mud is one of the requirements for mangroves to be able to live, along with tidal waves from the ocean (Matatula et al. 2018). Mud thickness variations in mangrove Tarus is shown in Figure 3 .

Table 1. Salinity, mud thickness and slope values at different sampling lines of Tarus mangrove location, Kupang District, East Nusa Tenggara, Indonesia

\begin{tabular}{llcllc}
\hline $\begin{array}{c}\text { Salinity } \\
(\mathbf{p p m})\end{array}$ & $\begin{array}{c}\text { Thickness } \\
\text { of mud } \\
(\mathbf{c m})\end{array}$ & $\begin{array}{c}\text { Slope } \\
(\mathbf{\%})\end{array}$ & $\begin{array}{c}\text { Salinity } \\
(\mathbf{p p m})\end{array}$ & $\begin{array}{c}\text { Thickness } \\
\text { of mud } \\
(\mathbf{c m})\end{array}$ & $\begin{array}{c}\text { Slope } \\
(\mathbf{\%})\end{array}$ \\
\hline 10 & 33 & 3 & 23.66 & 26 & 2 \\
10 & 30 & 2 & 23 & 30 & 2 \\
14 & 35.64 & 2 & 23.66 & 47.77 & 2 \\
16 & 35.64 & 2 & 24 & 41.44 & 3 \\
17.33 & 37.88 & 2 & 24 & 46.88 & 3 \\
17.33 & 43.22 & 2 & 24 & 45 & 3 \\
16 & 42.22 & 2 & 23.33 & 45.7 & 3 \\
18 & 47.88 & 2 & 23.33 & 20,11 & 2 \\
18 & 35 & 2 & 22.33 & 25 & 2 \\
18 & 42 & 2 & 23 & 24.77 & 2 \\
20 & 42 & 2 & 22 & 29.77 & 2 \\
20 & 43.7 & 2 & 20 & 20.11 & 2 \\
20 & 40.55 & 2 & 18 & 46.33 & 2 \\
20 & 43.11 & 2 & 18 & 44.22 & 2 \\
21 & 45.77 & 2 & 19.33 & 46.44 & 3 \\
21 & 40.55 & 2 & 19 & 43 & 2 \\
21 & 43.7 & 2 & 18 & 43.3 & 2 \\
21 & 46.11 & 2 & 18 & 47.55 & 2 \\
20.33 & 46 & 3 & 18.66 & 47.55 & 2 \\
20.66 & 40.55 & 2 & 18 & 29.77 & 2 \\
20.66 & 53.55 & 2 & 18 & 29.77 & 2 \\
22.66 & 26.5 & 2 & 18 & 29.77 & 2 \\
24 & 26.5 & 3 & 18 & 35.64 & 3 \\
\hline & & & & &
\end{tabular}


In addition to salinity and mud thickness, the slope of coastal area also plays a part in the growth of mangrove vegetations. Tarus has $2 \%$ slope in 37 lines, and $3 \%$ slope in 9 measurement lines. Tides and slope are two interconnected elements. The characteristics of coast such as the width, coastal line length, etc. are closely connected with waterlogging and sedimentation. Ideal habitat conditions will boost regeneration process greatly, especially in the budding of the seeds such as Avicennia marina (Hastuti et al. 2016). Inclination condition of mangrove Tarus can be seen in Figure 4. The analyzed physicochemical conditions of the Tarus mangrove forest area showed similarity with Mata Air location. This was illustrated by cluster analysis (Figure 17). This similarity may be due to the fact that these two locations are situated close to each other (Figure 1).
Physicochemical conditions of Mata Air mangrove location

Mata Air research location had salinity of $16 \mathrm{ppm}-30$ ppm, mud thickness of $21 \mathrm{~cm}-56.22 \mathrm{~cm}$, and slope of $2-3 \%$ (Table 2). Salinity value in Mata Air shows that it is within the limit of ideal salinity for growth of mangrove vegetation (Saparinto 2007). The dominant salinity value is $20.66 \mathrm{ppm}$, found in 33 out of total 134 sampling lines. Variation in salinity levels along the sampling lines of Mata Air is shown in Figure 5.

Dominant mud thickness in mangrove Mata Air was between $40 \mathrm{~cm}$ and $43.11 \mathrm{~cm}$ and its variation is shown in Figure 6 . The slope varies from $2 \%$ to $3 \%$. The dominant coastal slope was $2 \%$ found in 84 sampling lines. $2.33 \%$ slope was found in 17 lines, $2.66 \%$ in 2 lines and $3 \%$ slope was found in 28 lines (Figure 7). Dendrogram analysis indicated that this location shares the shortest distance with Tarus mangrove location (Figure 17).

Table 2. Salinity, mud thickness, and slope values at different sampling lines of Mata air mangrove location, Kupang District, East Nusa Tenggara, Indonesia

\begin{tabular}{|c|c|c|c|c|c|c|c|c|c|c|c|}
\hline $\begin{array}{c}\text { Salinity } \\
\text { (ppm) }\end{array}$ & $\begin{array}{c}\text { Thickness } \\
\text { of mud } \\
\text { (cm) }\end{array}$ & $\begin{array}{c}\text { Slope } \\
(\%)\end{array}$ & $\begin{array}{c}\text { Salinity } \\
\text { (ppm) }\end{array}$ & $\begin{array}{c}\text { Thickness } \\
\text { of mud } \\
(\mathrm{cm})\end{array}$ & $\begin{array}{c}\text { Slope } \\
(\%)\end{array}$ & $\begin{array}{c}\text { Salinity } \\
\text { (ppm) }\end{array}$ & $\begin{array}{c}\text { Thickness } \\
\text { of mud } \\
(\mathrm{cm})\end{array}$ & $\begin{array}{c}\text { Slope } \\
(\%)\end{array}$ & $\begin{array}{c}\text { Salinity } \\
\text { (ppm) }\end{array}$ & $\begin{array}{c}\text { Thickness } \\
\text { of mud } \\
(\mathrm{cm})\end{array}$ & $\begin{array}{c}\text { Slope } \\
(\%)\end{array}$ \\
\hline 22.66 & 34.88 & 2.33 & 20 & 32.66 & 2 & 24 & 45 & 3 & 24 & 31 & 2 \\
\hline 21.66 & 34.88 & 2.33 & 18 & 38.77 & 2 & 23 & 42 & 2 & 24 & 30 & 2 \\
\hline 18.66 & 33.33 & 2 & 18 & 39.55 & 2 & 23.66 & 50.88 & 3 & 24 & 39.44 & 2 \\
\hline 16 & 33.33 & 2.33 & 19.33 & 47.11 & 2.33 & 24 & 43.11 & 3 & 23 & 43.44 & 2 \\
\hline 18 & 43.88 & 3 & 20 & 43.11 & 2.33 & 24 & 44.88 & 3 & 23.33 & 49.44 & 2.33 \\
\hline 17.33 & 42.33 & 2 & 20 & 43.33 & 2.33 & 24 & 39.66 & 3 & 23 & 43.22 & 2 \\
\hline 23.33 & 44.55 & 2 & 20 & 40.33 & 2.33 & 23.33 & 32.66 & 3 & 23.33 & 42 & 3 \\
\hline 30 & 42.77 & 2 & 18.66 & 44.22 & 2 & 23.33 & 34 & 2 & 23.66 & 44.44 & 3 \\
\hline 21.66 & 33.88 & 2 & 18.66 & 40.33 & 2 & 22.66 & 31 & 2 & 23.33 & 49.33 & 2 \\
\hline 18.66 & 33.88 & 3 & 18.66 & 46 & 2 & 23 & 31.33 & 2 & 23.33 & 44.55 & 3 \\
\hline 20 & 33.33 & 2 & 18.66 & 36.44 & 2.33 & 22 & 37.88 & 2 & 23 & 40.22 & 2 \\
\hline 20 & 37.55 & 3 & 18 & 56.22 & 3 & 20 & 40.44 & 2 & 23 & 44.55 & 3 \\
\hline 20 & 34.66 & 2 & 18 & 25.44 & 3 & 18 & 52 & 2 & 23.33 & 45 & 2 \\
\hline 20 & 43.11 & 3 & 18.66 & 25.44 & 3 & 18 & 43.22 & 2 & 29 & 45.33 & 2 \\
\hline 22.66 & 40.22 & 2 & 18.66 & 26.55 & 2 & 19.33 & 41.77 & 3 & 23.66 & 48.22 & 2 \\
\hline 22.66 & 43.66 & 2 & 20.66 & 21 & 2 & 21 & 43.49 & 2 & 24 & 37.44 & 3 \\
\hline 23 & 44.11 & 2 & 21 & 30 & 2 & 18 & 43.33 & 2 & 24 & 38 & 3 \\
\hline 23 & 46.55 & 2 & 22 & 48.44 & 2 & 18 & 29.88 & 2 & 24 & 38.33 & 3 \\
\hline 23 & 44.11 & 3 & 20 & 45.11 & 2.33 & 22 & 31.66 & 2 & 23.33 & 37.11 & 3 \\
\hline 21.33 & 41.33 & 2 & 20 & 48.88 & 2.33 & 23 & 27.77 & 2 & 23.33 & 36 & 2 \\
\hline 22 & 41.33 & 2.66 & 20 & 34.11 & 2 & 23 & 37 & 2 & 23.66 & 40 & 2 \\
\hline 22.66 & 46.55 & 2.66 & 20 & 46.55 & 2 & 23 & 31 & 2 & 24 & 32.66 & 2.33 \\
\hline 24 & 43.11 & 3 & 22 & 56.22 & 2 & 23 & 29.88 & 2.33 & 24 & 42 & 2 \\
\hline 23.66 & 43.11 & 2 & 22 & 42.22 & 2 & 22 & 29.88 & 3 & 24 & 45 & 2 \\
\hline 23 & 40.33 & 2 & 20 & 36.44 & 2 & 22 & 32 & 2 & 24 & 44.55 & 2.33 \\
\hline 23.66 & 44.22 & 2 & 20 & 42.44 & 2 & 22.33 & 32.66 & 2 & 24 & 45 & 2 \\
\hline 24 & 40.33 & 3 & 21 & 56.22 & 2 & 22 & 35.44 & 2 & 24 & 35.88 & 3 \\
\hline 24 & 47.11 & 3 & 21 & 42.22 & 2 & 21.33 & 47.22 & 2 & 24 & 36.33 & 2 \\
\hline 24 & 40 & 3 & 21 & 42.22 & 2 & 21.33 & 48.44 & 2 & 24 & 44.55 & 2 \\
\hline 22.33 & 40 & 3 & 21 & 41.44 & 2 & 22.33 & 43.55 & 2.33 & 23.33 & 32.22 & 2 \\
\hline 23.33 & 36.44 & 2 & 20.33 & 41.33 & 3 & 23.66 & 50 & 2.33 & 24 & 37.88 & 2 \\
\hline 23.33 & 40 & 2 & 20.66 & 43.66 & 2 & 24 & 50.44 & 2 & 24 & 34.22 & 2 \\
\hline 23 & 40 & 2 & 20.66 & 42 & 2 & 24 & 54.44 & 2.33 & & & \\
\hline 22 & 38.77 & 2 & 22.66 & 45.88 & 2 & 24 & 31.66 & 2 & & & \\
\hline
\end{tabular}




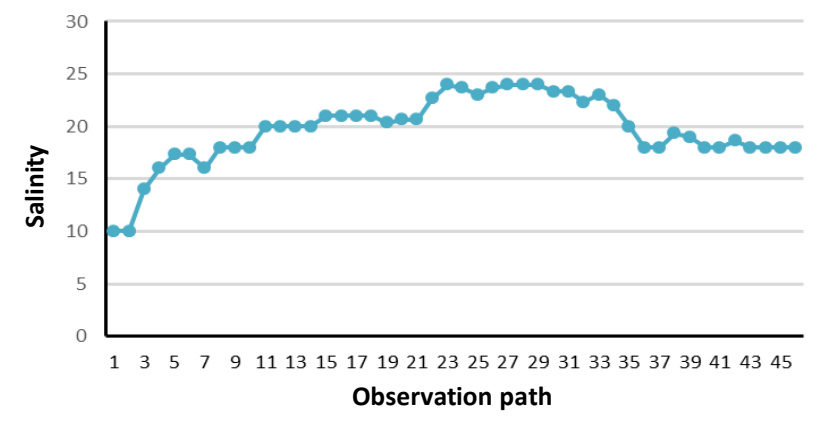

Figure 2. Salinity levels in different sampling lines of Tarus mangrove location

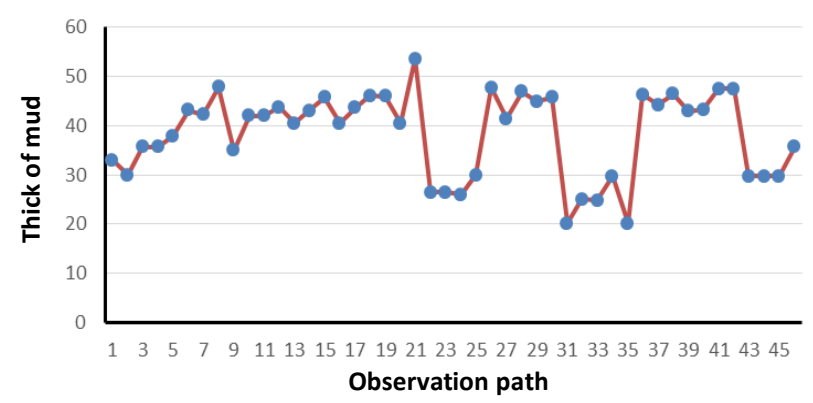

Figure 3. Mud thickness variation in different sampling lines of Tarus mangrove location.

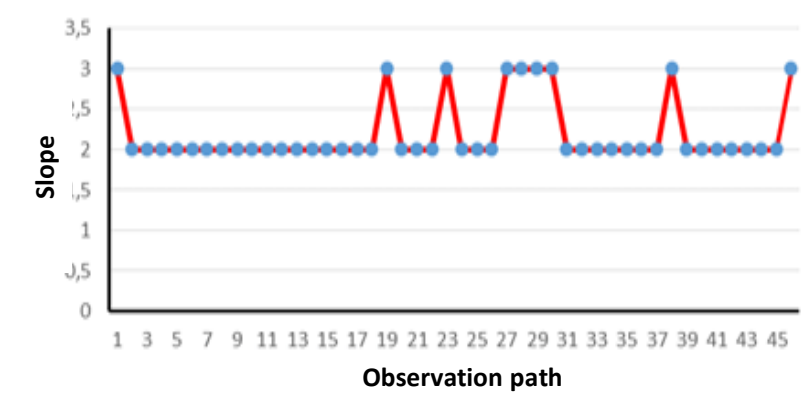

Figure 4. Coastal slope variation in sampling lines of Tarus mangrove location.

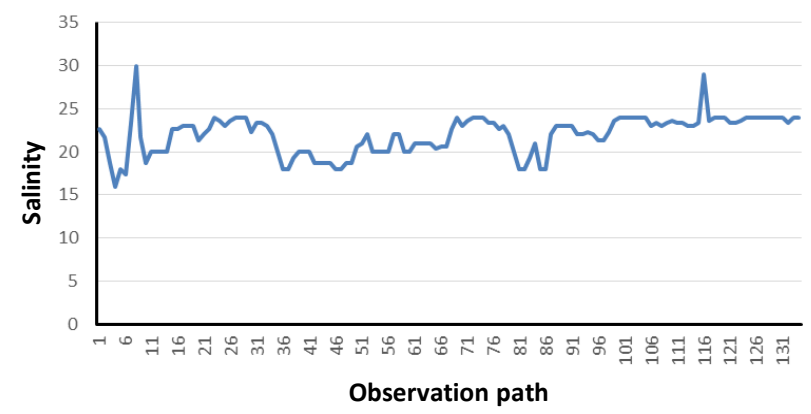

Figure 5. Salinity variation in sampling lines of Mata Air mangrove location

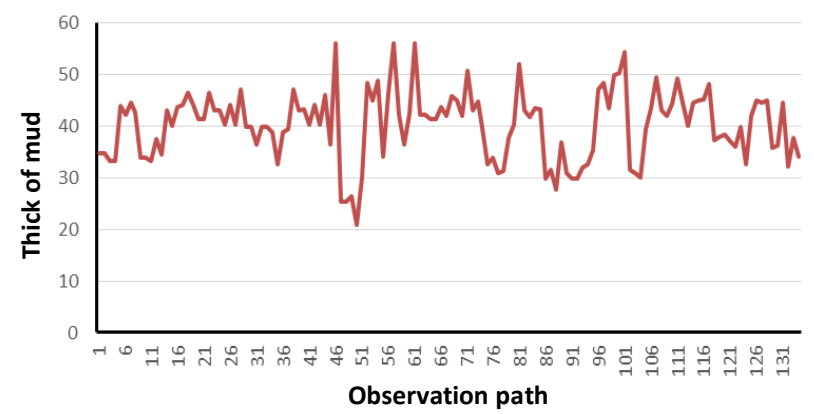

Figure 6. Variation in mud thickness along the sampling lines of Mata Air mangrove location

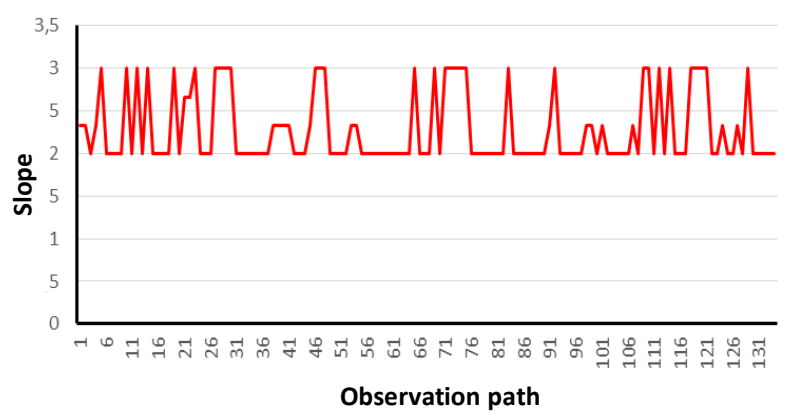

Figure 7. Slope variation across sampling lines of Mata Air mangrove location

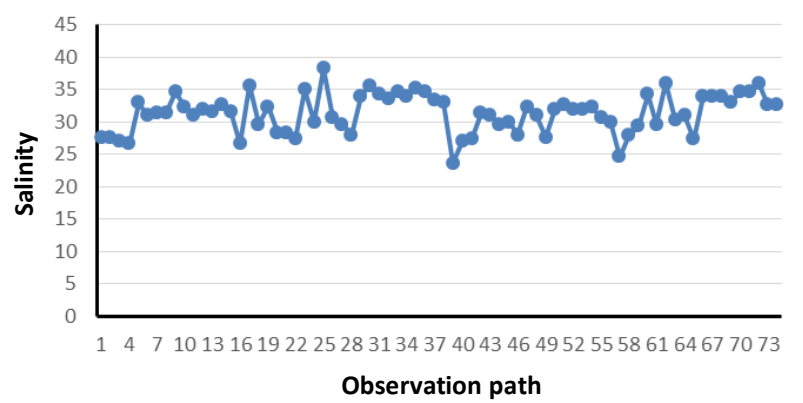

Figure 8. Salinity variation in sampling lines of Tanah Merah mangrove location

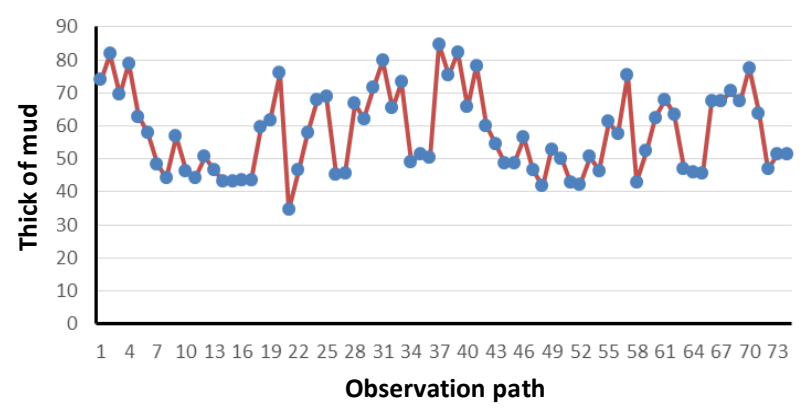

Figure 9. Variation in thickness of mud along sampling lines of Tanah Merah mangrove location 


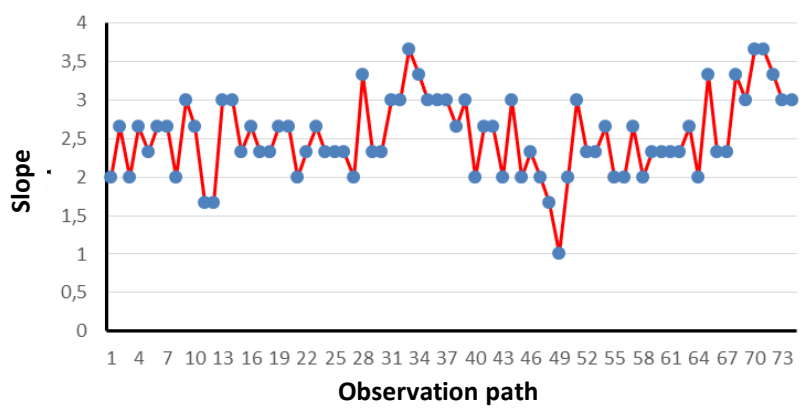

Figure 10. Slope variation in sampling lines of Tanah Merah mangrove location

\section{Physicochemical conditions of Tanah Merah mangrove location}

Physicochemical conditions of mangrove area of Tanah Merah is presented in Table 3. The salinity level ranged between $23.66 \mathrm{ppm}-38.33 \mathrm{ppm}$, from a total of 74 observation lines. The dominant salinity values were 31 ppm, $34 \mathrm{ppm}$ and $34.66 \mathrm{ppm}$, each of these values were found in 5 observation lines (Figure 8). Salinity level in Tanah Merah was comparatively higher, but still habitable for mangroves. This is in accordance with Purnobasuki et al. (2016) who opines that mangrove has a role in building the stability of coastal ecosystem because mangroves can grow in high salinity area and can survive in high tide.

Mud thickness at this location varies from $34.55 \mathrm{~cm}$ to $84.77 \mathrm{~cm}$ (Figure 9). The dominant inclination of $2.33 \%$ was found in 18 lines from a total of 74 observation lines. Inclination of $2.66 \%$ was found in 16 lines while $2 \%$ and $3 \%$ were found in 14 lines each, and $3.66 \%$ was found in 5 observation lines (Figure 10). This shows that the inclination in mangrove area of Tanah Merah as almost flat to low, and low inclination to steep. This is different from the study conducted on the eastern coast of Sumatra Utara, with slope of $<2 \%$ (Kusmana 2018). According to the cluster analysis result (Figure 17), this location showed similarity with Oebelo mangrove location.

\section{Physicochemical conditions of Oebelo mangrove location}

Physicochemical conditions of Oebelo location is summarized in Table 4. Salinity in Oebelo mangrove location was varying between $26.66 \mathrm{ppm}$ and $35.66 \mathrm{ppm}$. Dominant salinity was $33.33 \mathrm{ppm}$ found in 4 out of 37 total observation lines. Salinity values of $32.33 \mathrm{ppm}, 33.66 \mathrm{ppm}$, and $35.66 \mathrm{ppm}$ was found in 3 observation lines each while $30 \mathrm{ppm}, 33 \mathrm{ppm}, 34.33 \mathrm{ppm}$ and $35 \mathrm{ppm}$ found in 2 observation lines each (Figure 11). Salinity condition of this location can be categorized as moderate to high (Poedjirahajoe 2006). Mud thickness ranged from $32.77 \mathrm{~cm}$ to $74.66 \mathrm{~cm}$. Dominant values were $38 \mathrm{~cm}$ and $39.55 \mathrm{~cm}$, which were found in three observation lines. Mud thickness in other lines was highly variable, wherein the same thickness was recorded only in 1-2 lines (Figures 12). Oebelo shows slope levels of $2-3 \%, 2.33 \%$ being the dominant value found in 13 observation lines. $2 \%$ inclination was found in 10 observation lines, $2.66 \%$ in 6 observation lines, and 3\% is found in 8 observation lines (Figure 13). Slope of Oebelo location was categorized as almost flat to slope (Poedjirahajoe. 2006), which is similar to the slope condition found in Tarus, Mata Air and Merdeka areas. Oebelo mangrove area shows similarities with previously described Tanah Merah location because these two locations are close by in Figure 17.

Table 3. Salinity, mud thickness and slope values at different sampling lines of Tanah Merah mangrove location, Kupang District, East Nusa Tenggara, Indonesia

\begin{tabular}{|c|c|c|c|c|c|c|c|c|c|c|c|}
\hline $\begin{array}{l}\text { Salinity } \\
\text { (ppm) }\end{array}$ & $\begin{array}{l}\text { Thickness of } \\
\text { Mud }(\mathrm{cm})\end{array}$ & $\begin{array}{c}\text { Slope } \\
(\%)\end{array}$ & $\begin{array}{c}\text { Salinity } \\
\text { (ppm) }\end{array}$ & $\begin{array}{l}\text { Thickness of } \\
\text { mud }(\mathrm{cm})\end{array}$ & $\begin{array}{c}\text { Slope } \\
(\%)\end{array}$ & $\begin{array}{c}\text { Salinity } \\
\text { (ppm) }\end{array}$ & $\begin{array}{l}\text { Thickness of } \\
\text { Mud }(\mathrm{cm})\end{array}$ & $\begin{array}{c}\text { Slope } \\
(\%)\end{array}$ & $\begin{array}{l}\text { Salinity } \\
\text { (ppm) }\end{array}$ & $\begin{array}{l}\text { Thickness of } \\
\text { Mud (cm) }\end{array}$ & $\begin{array}{c}\text { Slope } \\
(\%)\end{array}$ \\
\hline 27.66 & 74 & 2 & 28.33 & 76 & 2.66 & 23.66 & 82.33 & 3 & 28 & 43 & 2 \\
\hline 27.66 & 81.88 & 2.66 & 28.33 & 34.55 & 2 & 27 & 65.66 & 2 & 29.33 & 52.44 & 2.33 \\
\hline 27 & 69.55 & 2 & 27.33 & 46.55 & 2.33 & 27.33 & 78.22 & 2.66 & 34.33 & 62.44 & 2.33 \\
\hline 26.66 & 78.88 & 2.66 & 35 & 57.88 & 2.66 & 31.33 & 60.11 & 2.66 & 29.66 & 68 & 2.33 \\
\hline 33 & 62.88 & 2.33 & 30 & 68 & 2.33 & 31 & 54.55 & 2 & 36 & 63.55 & 2.33 \\
\hline 31 & 58 & 2.66 & 38.33 & 68.88 & 2.33 & 29.66 & 48.55 & 3 & 30.33 & 47.11 & 2.66 \\
\hline 31.33 & 48.44 & 2.66 & 30.66 & 45.22 & 2.33 & 30 & 48.55 & 2 & 31 & 46 & 2 \\
\hline 31.33 & 44.22 & 2 & 29.66 & 45.77 & 2 & 28 & 56.44 & 2.33 & 27.33 & 45.66 & 3.33 \\
\hline 34.66 & 56.77 & 3 & 28 & 66.77 & 3.33 & 32.33 & 46.66 & 2 & 34 & 67.44 & 2.33 \\
\hline 32.33 & 46.33 & 2.66 & 34 & 62.11 & 2.33 & 31 & 41.77 & 1.66 & 34 & 67.44 & 2.33 \\
\hline 31 & 44.11 & 1.66 & 35.66 & 71.66 & 2.33 & 27.66 & 52.88 & 1.66 & 34 & 70.55 & 3.33 \\
\hline 32 & 50.66 & 1.66 & 34.33 & 79.77 & 3 & 32 & 50.22 & 2 & 33 & 67.44 & 3 \\
\hline 31.66 & 46.66 & 3 & 33.66 & 65.33 & 3 & 32.66 & 43 & 3 & 34.66 & 77.55 & 3 \\
\hline 32.66 & 43.11 & 3 & 34.66 & 73.33 & 3.66 & 32 & 42.22 & 2.32 & 34.66 & 63.88 & 3.66 \\
\hline 31.66 & 43.33 & 2.33 & 34 & 48.88 & 3.33 & 32 & 50.66 & 2.33 & 36 & 46.88 & 3.33 \\
\hline 26.66 & 43.66 & 2.66 & 35.33 & 51.55 & 3 & 32.33 & 46.44 & 2.66 & 32.66 & 51.44 & 3 \\
\hline 35.66 & 43.66 & 2.33 & 34.66 & 50.55 & 3 & 30.66 & 61.22 & 2 & 32.66 & 51.44 & 3 \\
\hline 29.66 & 59.66 & 2.33 & 33.33 & 84.77 & 3 & 30 & 57.55 & 2 & & & \\
\hline 32.33 & 61.66 & 2.66 & 33 & 75.33 & 2.66 & 24.66 & 75.44 & 2.66 & & & \\
\hline
\end{tabular}


Table 4. Salinity, mud thickness and slope values at different sampling lines of Oebolo mangrove location, Kupang District, East Nusa Tenggara, Indonesia

\begin{tabular}{|c|c|c|c|c|c|c|c|c|}
\hline $\begin{array}{l}\text { Salinity } \\
\text { (ppm) }\end{array}$ & $\begin{array}{l}\text { Thickness of } \\
\text { Mud (cm) }\end{array}$ & $\begin{array}{l}\text { Slope } \\
(\%)\end{array}$ & $\begin{array}{l}\text { Salinity } \\
\text { (ppm) }\end{array}$ & $\begin{array}{l}\text { Thickness of mud } \\
\text { (cm) }\end{array}$ & $\begin{array}{l}\text { Slope } \\
(\%)\end{array}$ & $\begin{array}{c}\text { Salinity } \\
\text { (ppm) }\end{array}$ & $\begin{array}{l}\text { Thickness of } \\
\text { mud } \\
(\mathrm{cm})\end{array}$ & $\begin{array}{l}\text { Slope } \\
(\%)\end{array}$ \\
\hline 33.66 & 69.55 & 2 & 31.66 & 41.77 & 2.66 & 34.66 & 44.88 & 2 \\
\hline 33.33 & 73.22 & 2 & 33.33 & 49.44 & 2.66 & 33.33 & 38.55 & 3 \\
\hline 33.33 & 61.33 & 2 & 26.66 & 32.77 & 2.33 & 35.66 & 38.11 & 2.33 \\
\hline 35 & 74.66 & 2 & 29 & 40 & 2.33 & 35.33 & 38 & 2.33 \\
\hline 33 & 62.44 & 2 & 29.33 & 39.55 & 2.33 & 35.66 & 38 & 3 \\
\hline 31 & 56.44 & 2.33 & 29 & 33.88 & 2.33 & 33.66 & 34.22 & 3 \\
\hline 32.33 & 45 & 2.66 & 30 & 40 & 2.33 & 35 & 33.88 & 3 \\
\hline 32.66 & 43.66 & 2 & 29.33 & 39.55 & 2.33 & 34.33 & 39.55 & 3 \\
\hline 34.33 & 53.77 & 2.33 & 27.33 & 38 & 2.33 & 35.66 & 39.66 & 3 \\
\hline 30 & 46.77 & 2.33 & 33.66 & 40.77 & 2.66 & 34.66 & 33.88 & 3 \\
\hline 31.33 & 42.55 & 2 & 31.33 & 44.22 & 2 & 34.66 & 38.55 & 3 \\
\hline 32.33 & 50.44 & 2 & 37 & 44.11 & 2.33 & & & \\
\hline 32.33 & 48.11 & 2.66 & 33 & 45.33 & 2.66 & & & \\
\hline
\end{tabular}

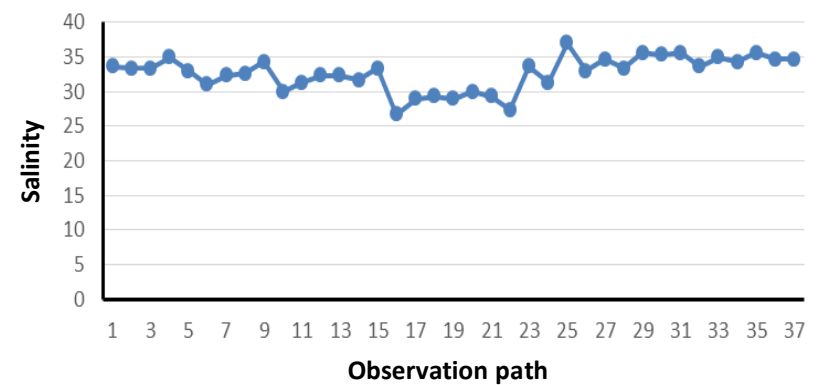

Figure 11. Variation in Salinity along sampling lines of Oebelo mangrove location

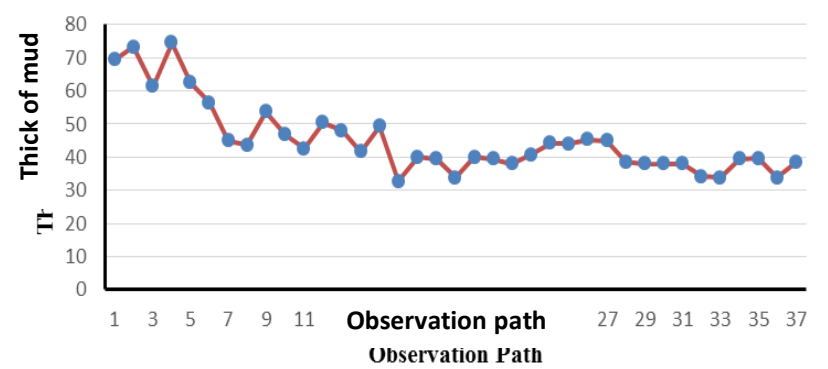

Figure 12. Variation in thickness of mud along sampling lines of Oebelo mangrove location

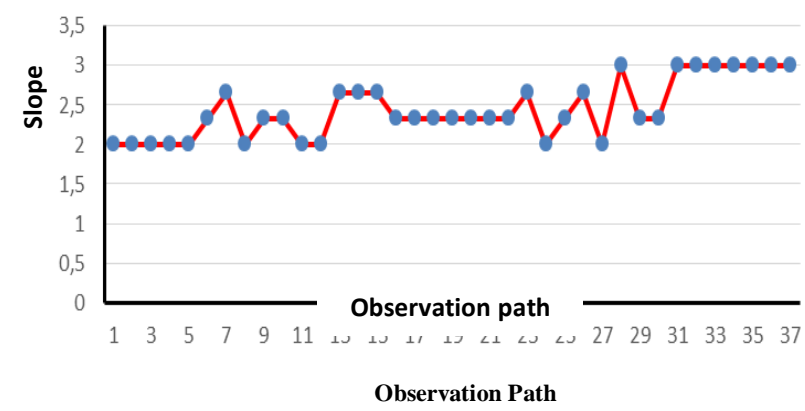

Figure 13. Variation in Slope along sampling lines of Oebelo mangrove location
Table 5. Salinity, mud thickness and slope values at different sampling lines of Merdeka mangrove location, Kupang District, East Nusa Tenggara, Indonesia

\begin{tabular}{lll}
\hline Salinity (ppm) & Thickness of mud $(\mathbf{c m})$ & Slope $(\%)$ \\
\hline 29 & 43.22 & 2.66 \\
28.66 & 43.22 & 3 \\
26 & 43.33 & 2 \\
28 & 49.22 & 2.33 \\
31 & 38.11 & 2.66 \\
34 & 38.11 & 3 \\
31.33 & 39.88 & 2.66 \\
31.33 & 38 & 2 \\
30.33 & 32 & 2.66 \\
29 & 48 & 2 \\
28.66 & 48.44 & 2.66 \\
28.66 & 53.66 & 3 \\
31.66 & 34.11 & 3 \\
32 & 43.33 & 3 \\
33 & 42.22 & 3 \\
\hline
\end{tabular}

\section{Physicochemical conditions of Merdeka mangrove location}

Values recorded for the assessed physicochemical parameters related to Merdeka mangrove location is shown in Table 5. Lowest salinity in this location was $26 \mathrm{ppm}$ and highest was $34 \mathrm{ppm}$. The spreading of different salinity levels is quite high (Figure 14). Dominant salinity levels of $28.66 \mathrm{ppm}$ and $31.33 \mathrm{ppm}$ were found in two observation lines. The other observation lines showed a variety of salinity levels. Salinity condition in mangrove Merdeka is categorized as moderate to high. Mud thickness ranges from $34.11 \mathrm{~cm}$ to $53.66 \mathrm{~cm}$, with dominant values of 38.11 $\mathrm{cm}, 43.22 \mathrm{~cm}$, and $43.33 \mathrm{~cm}$, each found in 2 observation lines (Figure 15). Mud thickness highly affects the ability of the vegetation's root system in trapping sediments brought along by the water flow of the tides (Noor et al. 1999). that the mud thickness would affect the durability of certain vegetations, root system could increase and stabilize mud. Mud thickness condition in the coastal area of mangrove Merdeka can be seen in Figure 18. 


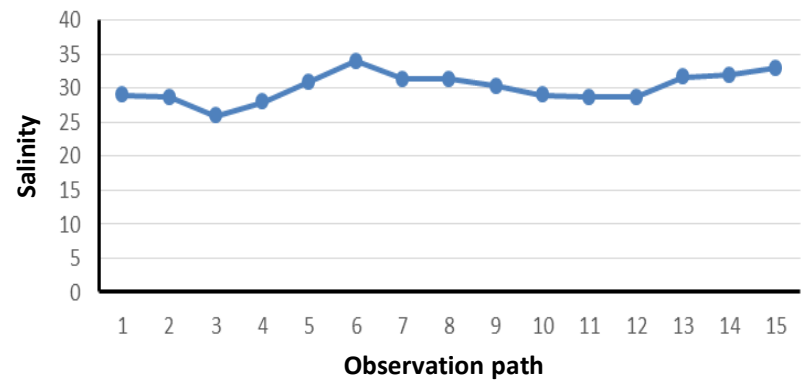

Figure 14. Variation in salinity along sampling lines of Merdeka mangrove location

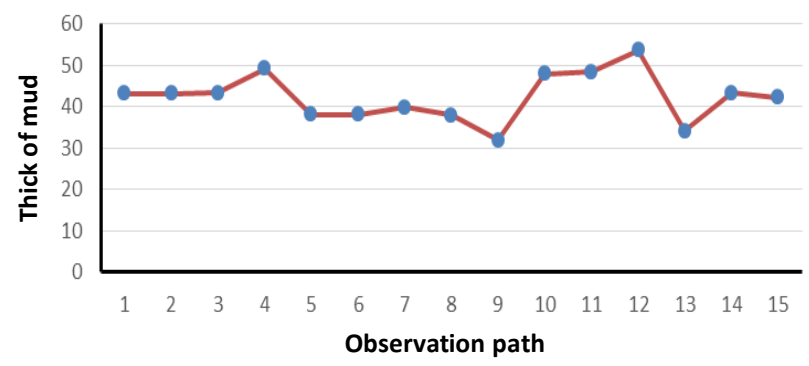

Figure 15. Variation in mud thickness along sampling lines of Merdeka mangrove location

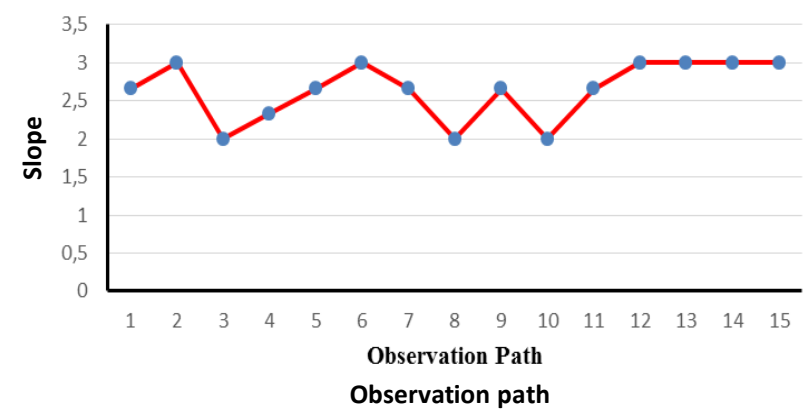

Figure 16. Variation in slope along samplıng lines of Merdeka mangrove location

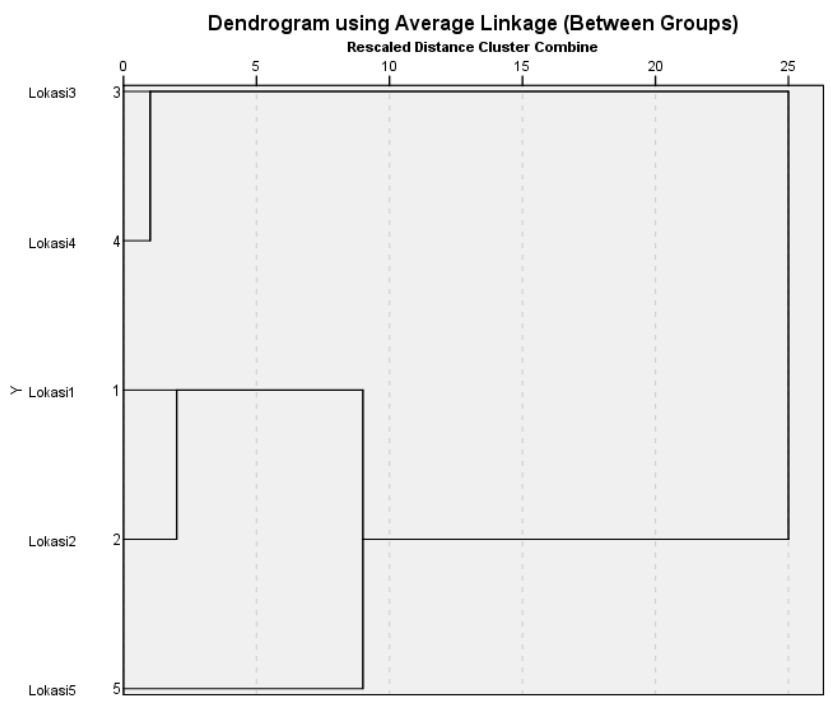

Figure 17. Dendrogram related to the assessed physicochemical parameters related to 5 mangrove locations of Kupang District, East Nusa Tenggara, Indonesia
Slope in mangroves of Merdeka range from 2\% to 3\%, while dominant slope is $3 \%$ which was found in 6 observation lines (Figure 16). Slope condition of Merdeka is categorized as almost flat to slopy (Poedjiraharjoe 2006). Dendrogram analysis result for environmental mangrove growth showed that Merdeka location has maximum similarities with Tarus and Mata Air locations. This is a surprising finding considering the fact that Merdeka location is geographically nearer to Oebelo and Tanah Merah locations.

\section{Mapping of physicochemical conditions of mangrove locations}

It is necessary to study the spatial distribution of species and their interaction with the ecosystem (Herliansyah and Fitria 2018). Spatial distribution of salinity, mud thickness, and slope conditions are needed which can form the basis for planning and managing coastal areas of Kupang District, East Nusa Tenggara. Distribution of salinity levels in all of the five studied mangrove locations of Kupang district is shown in Figure 18. Tarus shows low to moderate salinity shown by brown area dominating the front zone up to the middle zone, and low salinity is found in the back area of mangrove forest, indicated by green colors. The condition is different in Mata Air area, which shows the domination of pink colors in the front area, up to several places in the middle area of the mangrove forest. Salinity of the Tanah Merah and Oebelo locations are dominated by high levels. Merdeka is dominated by moderate to low salinity level areas. It is because Merdeka mangrove area is in the path of a river which becomes the border of mangroves of Merdeka and Nunkurus. Salinity conditions of all five locations when analyzed together shows a wide variation starting from $10 \mathrm{ppm}$ to $38.33 \mathrm{ppm}$. Mud thickness ranged from $20.11 \mathrm{~cm}$ to $84.77 \mathrm{~cm}$ in the entire study area. The highest mud thickness of $84.77 \mathrm{~cm}$ was found in Tanah Merah, followed by Oebelo with the maximum mud thickness of $74.66 \mathrm{~cm}$, Mata Air with 56.22 $\mathrm{cm}$, Merdeka with $53.66 \mathrm{~cm}$, and the lowest mud thickness was in Tarus with $53.55 \mathrm{~cm}$. The spatial distribution of mud thickness in the study locations is mapped in Figure 19. Mata Air, Tanah Merah, and Oebelo locations are dominated by dark green colors which indicate higher mud thickness. It may also be noted that thick mud dominates the coastal mangrove forests of Kupang District, starting from the front zone up to the middle zone.

Slope is related to the tide, which affects the characteristics of the beach, such as the width, coastline length, which in turn related to waterlogging and sedimentation. So, salinity and mud thickness are related to slope as well. Mangrove locations in Kupang District are dominated with 2-3\% slope, indicated by blue colors to pink colors in the map shown as Figure 20. The higher slope is indicated by a blue color, which dominates the front zone up to the middle, on almost all mangrove areas of Kupang District. Based on this study, it may be concluded that the habitat conditions of the studied mangrove areas of Kupang District are suitable for the growth of mangroves. 


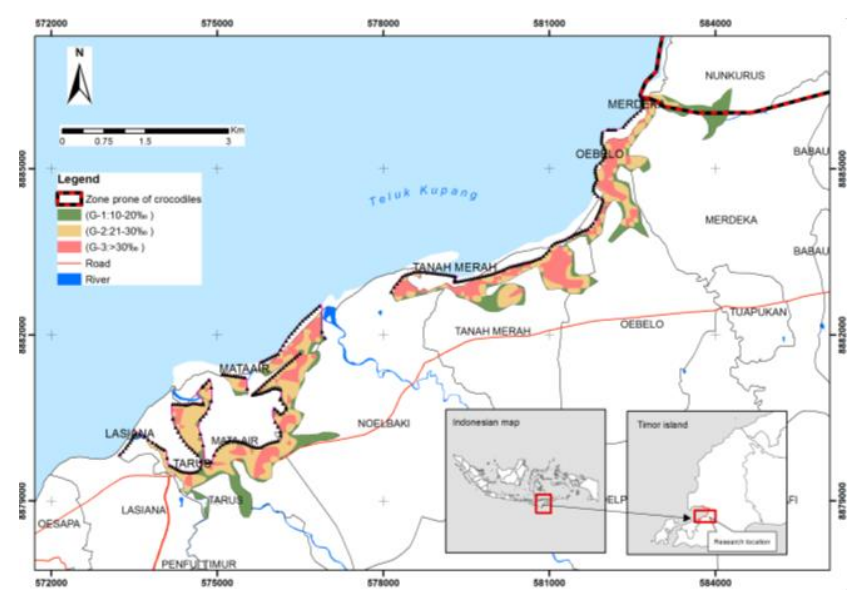

Figure18. Map showing the distribution of salinity levels in the mangrove locations of Kupang District, East Nusa Tenggara, Indonesia

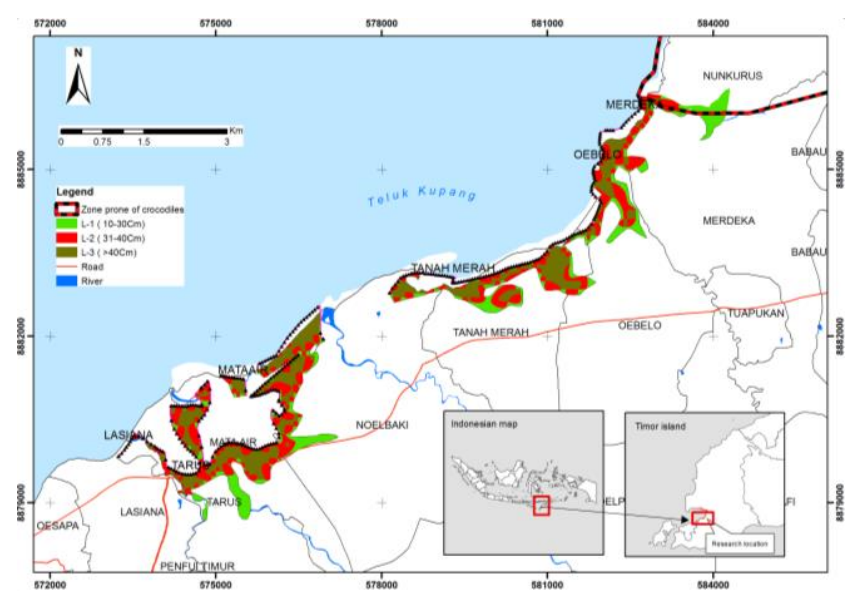

Figure 19. Map showing the distribution of mud thickness in the mangrove locations of Kupang District, East Nusa Tenggara, Indonesia

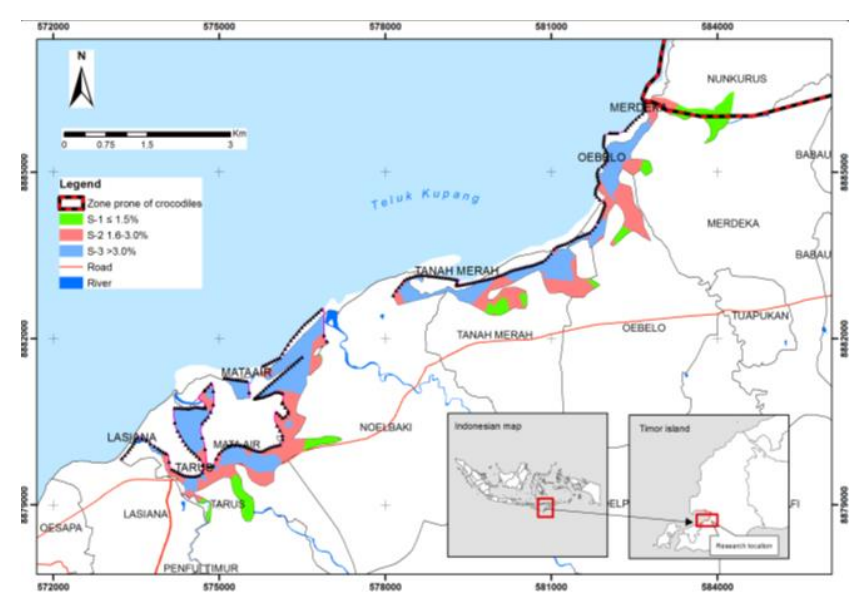

Figure 20. Map showing the distribution of slope in the mangrove locations of Kupang District, East Nusa Tenggara, Indonesia

\section{ACKNOWLEDGEMENTS}

We offer our most sincere gratitude to Natural Conservation Agency, East Nusa Tenggara who had given us permission to conduct this research in Kupang Cape. Also, we would like to thank the Ministry of Research, Technology and Higher Education, Indonesia for funding this research.

\section{REFERENCES}

Alongi DM. 2008. Mangrove Forests : Resilience, Protection from Tsunamis, and Responses to Global Climate Change. Elsevier, Nederlands.

Anneboina LR, Kumar KSK. 2012. Economic analysis of mangrove and marina fishery linkages in India. Ecosyst Serv 24: 114-123.

Basyuni M, Gultom K, Fitria BA, Susetya IE, Wati R, Slamet E, Balke T, Bunting P. 2018. Diversity and habitat characteristics of macrozoobenthos in the mangrove forest of Lubuk Kertang Village, North Sumatra, Indonesia. Biodiversitas 19 (1): .311-317.

Dharmawan B, Bocher M, Krott M. 2016. The failure of the mangrove conservation plan in Indonesia: Weak research and ignorance of grassroots politics. Ocean and Coastal Management, 130, pp.250-259.

Hastuti ED, Budihastuti E. 2016. Potential of mangrove seedlings for utilization in the maintenance of environmental quality within silvofishery ponds. Biotropia 2 (1): 58-63.

Herliansyah R, Fitria I. 2018. Latent variable models for multi-species counts modeling in ecology. Biodiversitas 19 (5): 1871-1876.

Husodo T, Palabbi SDG, Abdoellah OS, Nursaman M, Fitriani N, Partasasmita R. 2017. Short communication: Seagrass diversity and carbon sequestration: Case study on Pari Island, Jakarta Bay, Indonesia. Biodiversitas 18 (4): 1596-1601.

Kusmana C, Hidayat T, Istomo, Rusdiana O. 2018. Growth performance of Bruguiera gymnorrhiza derived from cut-propagule seedling. Biodiversitas 19 (1): 208-214.

Lapolo N, Utina R, Wahyuni DK, Baderan. 2018. Diversity and density of crabs in degraded mangrove area at Tanjung Panjang Nature Reserve in Gorontalo, Indonesia. Biodiversitas 19 (3): 1154-1159.

Ludwig JA, Reynolds JF. 1988. Statistical ecology. John Wiley and Sons, New York.

Manurung J, Iskandar Z, Siregar, Kusmana C, Dwiyanti FG. 2017. Genetic variation of the mangrove species Avicennia marina in heavy metal polluted estuaries of Cilegon Industrial Area, Indonesia. Biodiversitas 18 (3): 1109-1115.

Matatula J, Pathibang MR, Aryani NKAD, Ngaji AUK. 2018. Mangrove forest habitat conditions in Tanah Merah coastal beach East Nusa Tenggara. International conference on climate change, biodiversity, food security and local knowledge. Artha Wacana Christian University. Kupang, 3-4 September 2018.

Monsef HA, Smith S. 2018. Site selection for mangrove plantations along the Egyptian red sea coast. World Appl Sci J 3 (7): 740-747.

Noor YR, Khazali M, Suryadiputra INN. 1999. Panduan Pengenalan Mangrove di Indonesia. PHKA/WA-IP, Bogor [Indonesian].

Poedjirahajoe E. 2006. Klasifikasil lahan potensial untuk rehabilitasi mangrove di pantai utara Jawa Tengah (Rehabilitasi mangrove menggunakan enis Rhizopora mucronata). [Disertasi]. Universitas Gadjah Mada, Yogyakarta. [Indonesian].

Purnobasuki H, Utami ESD. 2016. Seed germination of Avicennia marina (Forsk.) Vierh . By Pericarp removal treatment. Biodiversitas 2 (2): 74-83.

Retnowati Y, Sembiring L, Moeljopawiro S, Djohan TS, Soetarto ES. 2017. Diversity of antibiotic-producing Actinomycetes in mangrove forest of Torosiaje, Gorontalo, Indonesia. Biodiversitas 18 (3): 14531461

Saparinto C. 2007. Pendayagunaan Ekosistem Mangrove. Effhar Offset Semarang. [Indonesia]

Widigdo B, Rukisah, Laga A, Hakim AA, Wardiatno Y. 2017. Carapace length-weight and width-weight relationships of Scylla serrata in Bulungan District, North Kalimantan, Indonesia. Biodiversitas 18 (4): 1316-1323.

Wiryanto, Sunarto, Rahayu SM. 2017. Biodiversity of mangrove aquatic fauna in Purworejo, Central Java, Indonesia. Biodiversitas 18 (4): 1344-1352. 